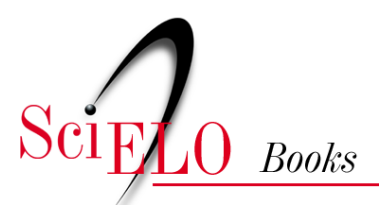

\title{
16. Episódio Macabro no Ensino de Anatomia
}

\author{
Joffre Marcondes de Rezende
}

\section{SciELO Books / SciELO Livros / SciELO Libros}

REZENDE, J. M. Episódio Macabro no Ensino de Anatomia. In: À sombra do plátano: crônicas de história da medicina [online]. São Paulo: Editora Unifesp, 2009, pp. 157-162. História da Medicina series, vol. 2. ISBN 978-85-61673-63-5. https://doi.org/10.7476/9788561673635.0017.

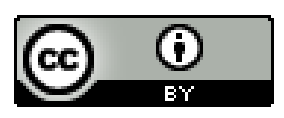

All the contents of this work, except where otherwise noted, is licensed under a Creative Commons Attribution 4.0 International license.

Todo o conteúdo deste trabalho, exceto quando houver ressalva, é publicado sob a licença Creative Commons Atribição 4.0.

Todo el contenido de esta obra, excepto donde se indique lo contrario, está bajo licencia de la licencia Creative Commons Reconocimento 4.0. 


\section{Episódio Macabro no Ensino de Anatomia}

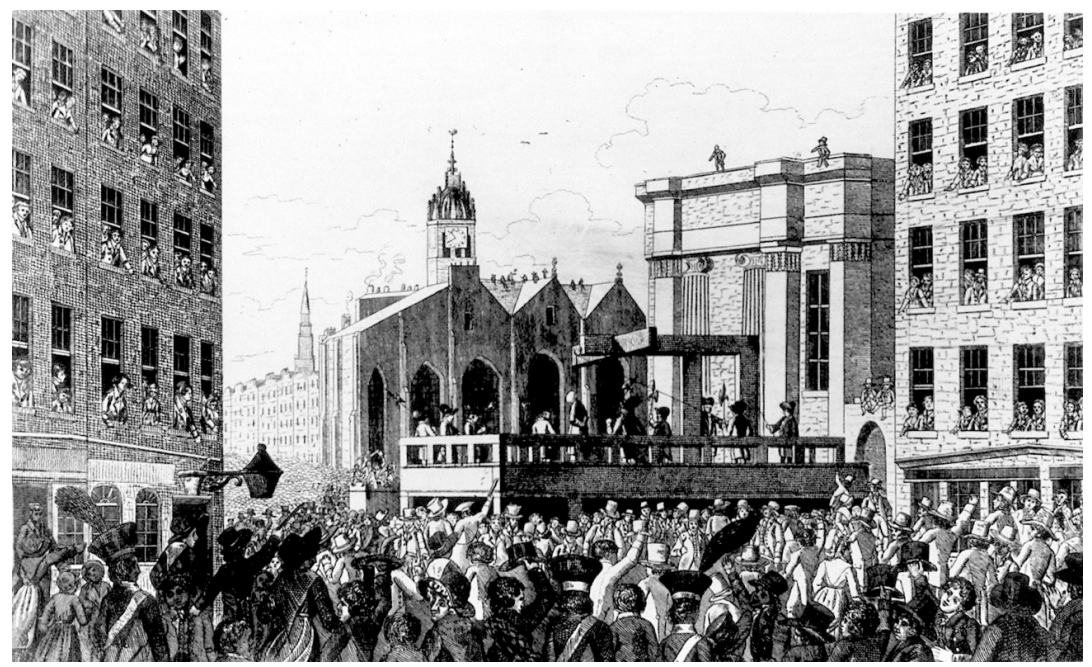

Execução de Burke na forca em 29 de janeiro de I 829.

o século xviıI, Edimburgo, na Grã-Bretanha, era um grande centro
de estudos anatômicos. Na universidade, a cátedra de Anatomia foi ocupada pela dinastia dos Monro por três gerações.

O primeiro deles, Alexander Monro primus lecionou de I 720 a I 758 , tendo sido substituído por seu filho Alexander Monro secundus, que se destacou como autor de quatro importantes obras de anatomia, numa das quais, publicada em I797, descreveu o chamado "buraco de Monro". Sucedeu-lhe seu filho, Alexander Monro tertius, que não possuía as qualidades do pai, e o ensino de anatomia na universidade entrou em declínio (Castiglioni, I93 I, p. I I 2).

$\mathrm{Na}$ época, era permitido o ensino paralelo em escolas e cursos privados. Para o ensino de anatomia destacava-se o curso extracurricular dirigido por John Barclay, anatomista de grande renome e prestígio internacional. Barclay convidou para ser seu assistente o dr. Robert Knox, que se tornou um dos personagens do episódio que vamos narrar. Antes, precisamos saber quem era Robert Knox. 
Robert Knox (I79I-I 862) era natural de Edimburgo, onde foi educado. No colégio fora um aluno brilhante, tendo sido premiado por seu desempenho nos estudos e conduta exemplar. Graduou-se em medicina em I8 I4, ingressando no ano seguinte no exército como cirurgião-auxiliar. Uma de suas primeiras atuações foi a de atender feridos da batalha de Waterloo. Em I 8 I 5 foi promovido a cirurgião-assistente, indo servir na África do Sul, onde permaneceu durante três anos.

Durante sua estada na África do Sul interessou-se por estudos de anatomia comparada, antropologia e características étnicas dos povos africanos.

Retornando a Edimburgo em i 82 I licenciou-se do Exército e foi estagiar em Paris com Cuvier, um dos grandes anatomistas da época. De volta a Edimburgo aceitou o convite de Barclay para ser seu assistente no curso de anatomia.

Entre I 82 I e I823, Knox publicou vários trabalhos científicos no Edinburgh Medical Journal e, em dezembro de I 823, foi eleito membro da Royal Society.

Barclay possuía uma grande coleção de peças anatômicas, que ele doou ao Royal College of Surgeons de Edimburgo para instalação de um museu de anatomia e, em I 825, Knox foi indicado para conservador do museu. Este museu foi enriquecido com outra grande coleção de anatomia e anatomia patológica adquirida pelo colégio, em Londres, de Charles Bell. Knox encarregou-se de organizar o museu, catalogando todas as peças.

Paralelamente a essas atividades, Knox firmou-se como professor de anatomia na escola de Barclay. Suas aulas eram muito apreciadas pelos alunos por seu conteúdo, exposição didática e, sobretudo, pelas demonstrações práticas em dissecções de cadáveres. Em agosto de I 826, Barclay faleceu e Knox assumiu a direção da escola, que contava, naquele ano, com trezentos alunos matriculados (MacLaren, 2000).

$\mathrm{Na}$ época, o ensino prático de anatomia era dificultado pela falta de cadáveres para dissecção. A dissecção só era legalmente permitida em corpos de criminosos condenados ao patíbulo, pois fazia parte da pena de morte negar ao criminoso sepultamento digno em terreno santificado pela Igreja.

O número de criminosos condenados à morte era insuficiente para prover as necessidades do ensino de anatomia. Em consequência, surgiu o mercado negro de cadáveres, os quais eram exumados por ladrões no cemitério, logo 
após o sepultamento, e vendidos às escolas médicas. Os cadáveres deviam ser recentes, pois não havia os métodos de conservação atuais. Os ladrões de cadáveres passaram a ser chamados de ressurreccionistas.

As famílias dos mortos, para se defenderem dos ressurreccionistas, costumavam proteger o túmulo com grades ou pagar vigias noturnos. Alguns cemitérios foram cercados de muros ou dispunham de torres de observação e policiamento contínuo. Mesmo assim, os ladrões de cadáveres conseguiam ludibriar toda a vigilância.

Curiosamente, os ressurreccionistas, quando acusados, não eram condenados, por falta de amparo legal, pois não havia lei prevendo este tipo de crime e a violação da sepultura não se enquadrava como roubo, já que o cadáver não é propriedade de ninguém (BвC, s.d.).

Foi nessa época e nesse ambiente que ocorreu o episódio macabro que abalou a opinião pública, não somente na Grã-Bretanha, como em todo o mundo. Dois irlandeses, William Hare e William Burke, que residiam em Edimburgo, cometeram uma série de assassinatos com o fim de vender os corpos das vítimas para dissecção nas aulas de anatomia.

William Hare residia em uma pensão, cujo proprietário, mr. Log, veio a falecer. Hare casou-se com a viúva, Margaret, passando da condição de hóspede a dono da pensão. William Burke e sua amante, Helen McDougal, foram residir na referida pensão como inquilinos.

Hare e Burke costumavam beber juntos e tornaram-se amigos. Em 29 de novembro de I 827 , um dos pensionistas, de nome Donald, aposentado que vivia só, morreu subitamente, deixando uma dívida para com a pensão. Hare teve a ideia de vender o cadáver para dissecção, com o fim de se ressarcir do prejuízo. Com a ajuda de Burke simulou o sepultamento, colocando no caixão um peso equivalente ao de uma pessoa.

Hare tencionava vender o corpo para Alexander Monro, na universidade, porém foi informado por um estudante que a escola de anatomia do dr. Knox pagaria um preço melhor. O corpo foi vendido para o dr. Knox por sete libras e dez xelins.

Encorajados com o sucesso da operação, perceberam ambos que a venda de cadáveres era um negócio muito lucrativo. Em lugar de violar sepulturas no cemitério, o que era trabalhoso e arriscado, idealizaram um processo mais fácil de obter o cadáver, que puseram em prática. A estratégia consistia em 
atrair para a pensão pessoas desamparadas, pedintes de rua, cuja morte não seria notada pela comunidade, passando despercebida. A primeira vítima rendeu-lhes dez libras.

A vítima era embriagada com uísque e, a seguir, morta por asfixia, comprimindo-se com um travesseiro ou almofada seu rosto, impedindo-a de respirar. Esse método não deixava vestígio da causa da morte. Burke se encarregava da execução e Hare de negociar a venda do corpo.

Os estudantes do curso de anatomia do dr. Knox passaram a desconfiar de que algo estranho estaria ocorrendo, dada a quantidade de corpos disponíveis para dissecção, todos em bom estado, ao contrário da escassez habitual.

Dois corpos chegaram a ser identificados por alguns estudantes: o de uma prostituta, de nome Mary Paterson, e o de um homem popular conhecido por Daft Jamie.

Comunicaram o fato ao dr. Knox, que não o levou em consideração, e os corpos foram imediatamente dissecados.

Durante o ano de I 828 pelo menos dezesseis corpos foram vendidos à escola de anatomia do dr. Knox. A última vítima foi o de uma irlandesa de nome Mary Docherty, que desapareceu da pensão de um dia para outro, levantando suspeitas entre os demais hóspedes, especialmente do casal Gray, que encontrou o corpo debaixo de uma cama. A polícia foi avisada, porém quando chegou à pensão o corpo não se encontrava no local. Alguns vizinhos, contudo, relataram ter visto dois homens carregando uma grande caixa de madeira. A polícia, já ciente da suspeita que pairava na escola de anatomia do dr. Knox, para lá se dirigiu, onde encontrou e identificou o corpo da vítima.

Em 24 de dezembro de I 828 foram presos Hare e sua mulher e Burke com sua amante. $\mathrm{Na}$ impossibilidade de obter uma prova concreta de que se tratava de assassinato, visto que não havia ferimentos ou sinais de violência no corpo da vítima, a polícia propôs a Hare que, se ele confessasse, somente Burke seria julgado pelo assassinato de Mary Docherty.

Hare contou toda a verdade e foi posto em liberdade juntamente com sua mulher. Burke foi julgado e condenado à forca. Sua amante, Helen McDougal, acusada de cumplicidade, foi absolvida por falta de provas.

Antes de sua morte, Burke confirmou que havia matado, ao todo, dezesseis pessoas, porém negou que jamais houvesse violado uma sepultura para roubo de cadáver. 
Sua execução, na forca, ocorreu no dia 29 de janeiro de 1829 e foi assistida por uma multidão de milhares de pessoas, de todas as classes sociais, que se acotovelavam para ver de perto o criminoso. Fazia parte da sentença que o seu corpo fosse publicamente dissecado pelo prof. Alexander Monro tertius, o que foi feito.

Durante a dissecção, em presença de estudantes e de curiosos, houve um tumulto e a maior parte da pele do criminoso, que já havia sido retira$\mathrm{da}$, desapareceu. Tempos depois apareceram à venda, livros encadernados com a pele curtida de Burke. Um de tais livros pode ser visto no museu da universidade, assim como o esqueleto de Burke.

$\mathrm{O}$ dr. Knox foi apontado como receptador dos corpos das vítimas assassinadas e levantou-se contra ele a suspeita de que teria conhecimento da procedência dos cadáveres. Como não se comprovou sua culpabilidade, ele não foi processado, porém caiu em desgraça perante a opinião pública. $\mathrm{O}$ seu curso de anatomia, que chegou a ter 504 alunos matriculados nos anos de I 827 e I 828 , esvaziou-se progressivamente.

Em I83 I, sentindo-se constrangido e alvo de desconfiança e de ataques, Knox deixou o cargo de conservador do museu e em I 842 mudou-se definitivamente para Londres, onde viveu os últimos anos de sua vida.

Hare fugiu para Londres, onde terminou seus dias como indigente. Ignora-se o destino de Margaret Hare e Helen McDougal.

Os fatos ocorridos em Edimburgo repercutiram intensamente no Parlamento Britânico, que promulgou, em I 832, o Anatomy Act, segundo o qual passou a ser permitido o uso de cadáveres não reclamados por familiares para o ensino de anatomia. Com isto extinguiu-se na Grã-Bretanha o mercado negro de cadáveres e a prática de roubo de corpos nos cemitérios.

Este macabro episódio ficou marcado na história da língua inglesa pela criação do neologismo burkism e do verbo to burk, com o sentido de sufocar, matar alguém para venda do cadáver, assassinar sem deixar vestígio (Oxford English Dictionary, I978; Houaiss e Cardim, I982).

\section{Referências Bibliográficas}

ввС. Disponível em http://www.bbc.co.uk/dna/h2g2/classic/A702802.html, acesso em 25 jun. 2003. 
Castiglioni, A. Histoire de la médecine. Paris, Payot, i93 I.

Houaiss, A. \& Cardim, I. (orgs.). Dicionário Webster's Inglês-Português. Rio de Janeiro, Record, I982.

MacLaren, I. "Robert Knox: The First Conservator of the College Museum”. Journal of the Royal College of Surgeons of Edinburgh, 45, pp. 392-397, 2000.

OXford English Dictionary (Shorter), $3^{\underline{a}}$ ed. Oxford, Claredon Press, 1978. 